\title{
Reproductive biology of Holothuria fuscocinerea (Echinodermata: Holothuroidea) from Oaxaca, Mexico
}

\author{
Francisco Benítez-Villalobos ${ }^{1, *}$, Omar Hernando Avila-Poveda ${ }^{2}$, \\ Itandehui Sarai Gutiérrez-Méndez ${ }^{2}$
}

\begin{abstract}
${ }^{1}$ Instituto de Recursos, and ${ }^{2}$ División de Estudios de Posgrado, Universidad del Mar (UMAR), Campus Puerto Ángel,
\end{abstract} Distrito de San Pedro Pochutla, CP 70902, Puerto Ángel, Oaxaca, Mexico

\begin{abstract}
The sea cucumber Holothuria fuscocinerea is among the most common holothurian species widely distributed in the Tropical Eastern Pacific Region and is becoming a potentially important fishery in Mexico. Nevertheless, there are no studies about its reproductive biology. This study analyzed several reproductive traits of $H$. fuscocinerea based on monthly time-series samples taken from April 2008 to March 2009 at La Entrega Bay, Oaxaca, in the Mexican tropical Pacific. Sex ratio, gonad development stages (GDS), reproductive cycle, diameter and distribution of oocytes, and fecundity were determined. Reproductive indices (the gonadosomatic index [GSI] and maturity index [MI]) were calculated, and their relationship with some environmental factors (temperature, rainfall, salinity, and $\mathrm{pH}$ ) was evaluated. $H$. fuscocinerea is a gonochoric holothuroid, and its annual ratio of males to females was not significantly different from 1:1. Four GDS (i.e. gametogenesis, mature, spawning, post-spawning) as well as one period of gonadal recovery, which is 'sexually undifferentiated', were established. Spawning occurred from June to October in females and from April to September in males. Post-spawning of females and males and recovery stages coincided from October to January. Mean fecundity was $2.9 \pm 2.8$ million oocytes per female, with ovaries exclusively comprised of vitellogenic oocytes from June to September. GSI and MI values showed similar variations in accordance with the reproductive cycle, and GSI showed a relationship with rainfall season. Seasonal rainfall may act as a cause of the seasonal reproductive pattern observed in $H$. fuscocinerea.
\end{abstract}

KEY WORDS: Gonad development stages $\cdot$ Reproductive cycle $\cdot$ Gonadosomatic index $\cdot$ Maturity index $\cdot$ Fecundity $\cdot$ Histology $\cdot$ Sea cucumber

\section{INTRODUCTION}

The use of holothurians as food has a long history, as they have been gathered since ancient times for celebrations in most South Asian countries and in countries where ethnic Chinese communities exist (Tiensongrusmee \& Pontjoprawiro 1988, Conand \& Byrne 1993, Lovatelli et al. 2004). Globally, holothurian fisheries are usually based on about 30 species from more than 1000 described within the order Aspidochirotida, although where intense fishing occurs, members of other orders, such as Dendrochirotida, are now in-

*Email: fbv@angel.umar.mx cluded (Tiensongrusmee \& Pontjoprawiro 1988, Lovatelli et al. 2004). The growing popularity of this fish has caused a rapid increase in the market price and an expansion of the sea cucumber fisheries worldwide, including Latin American countries (Conand \& Byrne 1993, Conand 2004, Toral-Granda et al. 2008, Anderson et al. 2011). For this reason, the Food and Agriculture Organization (FAO) has emphasized the necessity for basic research and assistance to the countries where sea cucumber populations are starting to be exploited or where knowledge is critically lacking. In addition, research should also be promoted in a wide

() The authors 2013. Open Access under Creative Commons by Attribution Licence. Use, distribution and reproduction are unrestricted. Authors and original publication must be credited. 
range of countries to compare the biological, ecological, and reproductive features of populations among different regions (Lovatelli et al. 2004, Andrew et al. 2007, Purcell et al. 2010, 2013).

Seasonality of ecosystems increases gradually from the tropics to the polar regions, which are highly seasonal. This pattern is modeled mainly by the annual cycle of solar energy received, and it is exacerbated in the marine environment by oceanic ice in winter (Priddle et al. 1986). This fact is important in regulating the reproductive activity of echinoderms, because there is dissimilarity in the patterns of reproductive periodicity which reflect the seasonal differences in the environment they inhabit (Lessios 1981, Byrne et al. 1997). It has been observed that species from the poles or high latitudes show a notable seasonality in reproduction (Stanwell-Smith \& Clarke 1998), which decreases in species from mid latitudes (Carvalho \& Ventura 2002, Rubilar et al. 2005) and is not evident in tropical species (Pearse 1968, Guzmán \& Guevara 2002).

Although several studies, especially in the genus Holothuria, have been carried out on sea cucumber reproduction and its relationship to environmental factors, both near the Equator (e.g. Pearse 1968, Conand 1993, Reichenbach 1999, Ramofafia et al. 2001, Abdel-Razek et al. 2005, Muthiga 2006, Gaudron et al. 2008, Muthiga \& Kawaka 2009) and at higher and lower latitudes (e.g. Gutt et al. 1992, Hudson et al. 2003, Despalatovi et al. 2004, Galley et al. 2008, Baillon et al. 2011, Martinez et al. 2011), a fundamental barrier to improvements in the management of sea cucumber fisheries is a lack of data regarding the basic biological parameters of the most exploited species (Conand \& Sloan 1989, Conand 2001, Lovatelli et al. 2004).

Holothurian fisheries along the coast of Mexico started in the late 1980s and focused on Isostichopus fuscus and Parastichopus parvimensis, reaching a national maximum harvest of 2000 and $700 \mathrm{t}$, respectively, around 1992 (Castro 1995, Aguilar-Ibarra \& Ramírez-Soberón 2002, SAGARPA 2012). Of these 2 species, the Mexican government declared only I. fuscus as 'threatened for extinction', and later this status was changed to 'subject to special protection', but without establishing precise specifications for its protection. Additionally, illegal fishing has been recorded, and the holothurian populations continue to decrease steadily (Aguilar-Ibarra \& RamírezSoberón 2002). Recently, fisheries of other sea cucumber species not mentioned in the official laws, such as Holothuria fuscocinerea and $H$. inornata, have been established in Mexico.
The ashy pink sea cucumber Holothuria fuscocinerea is among the most common holothurian species (Aspidochirotida: Holothuriidae) and is widely distributed in the Tropical Eastern Pacific Region from the Gulf of California, Mexico, to the Galapagos Islands, Ecuador, as well as in Australia, the Philippines, Singapore, Tonga, and Guam in the Western Pacific Region (Solís-Marín et al. 1997, Hickman 1998, Teo et al. 2010). Considering the current increase in extraction of this species for commercial purposes and the fact that many basic aspects of its reproductive biology are poorly understood or remain to be investigated, it is necessary to improve our knowledge about this potential resource. Therefore, an analysis of the main reproductive traits of $H$. fuscocinerea and their relationship to some environmental factors will contribute to our knowledge of its reproductive biology, which is a very important aspect in the context of an ecosystem approach to sea cucumber management (Purcell et al. 2010).

\section{MATERIALS AND METHODS}

\section{Collection and measurement}

About 19 individuals of Holothuria fuscocinerea were haphazardly collected by scuba diving on a monthly basis between April 2008 and May 2009 from a depth interval of 10 to $18 \mathrm{~m}$ in La Entrega Bay, Huatulco, Oaxaca $\left(15^{\circ} 44^{\prime} 34^{\prime \prime} \mathrm{N}, 96^{\circ} 07^{\prime} 35^{\prime \prime} \mathrm{W}\right)$, on the Pacific coast of southern Mexico. Individuals were narcotized by leaving them in seawater at $3^{\circ} \mathrm{C}$ for $12 \mathrm{~h}$ before dissection. The whole gonadal tubules (hereafter, gonad) were dissected by opening the ventral side of each sea cucumber, and the body, viscera, and gonads were allowed to drain until dampdried (around $5 \mathrm{~min}$ ) before being weighed. The total body weight (TBW, including viscera and gonad) and the gonad weight (GW) were recorded using an analytical balance $( \pm 0.001 \mathrm{~g})$. Gonad volumes $(\mathrm{GV} \pm$ $0.001 \mathrm{ml}$ ) were measured by displacement of the fluid method until a hydrostatic equilibrium was reached, using a variation of the Mohr-Westphal balance (Scherle 1970, Nagy \& Pieri 1975). Finally, the gonads were fixed in Bouin's solution for $3 \mathrm{~d}$ and later preserved in $70 \%$ ethanol saturated with lithium carbonate to remove the excess of picric acid from fixation (Humason 1962, Muñeton-Gómez et al. 2000).

Several environmental parameters were recorded monthly. Salinity and $\mathrm{pH}$ were measured using a waterproof multiparameter (HANNA $^{\circledR}$ HI 9828), while temperature was recorded at $1 \mathrm{~h}$ intervals 
using a pendant data logger (HOBO) permanently attached to the sea floor. Rainfall data (pluvial precipitation) were taken from the Mexican National Meteorology Service of the National Water Commission (SMN-CNA 2009) online database. Monthly means were calculated for temperature and pluvial precipitation.

\section{Histological procedure and microscopic examination}

Preserved gonads were washed in $70 \%$ ethanol and dehydrated in ethanol series, cleared in Citrisolv ${ }^{\circledR}$, infiltrated and embedded in paraffin wax. Serial sections were cut at $5 \mu \mathrm{m}$ thickness using a manual rotary microtome (LEICA RM2145), then mounted on glass slides, heated for $12 \mathrm{~h}$ at $60^{\circ} \mathrm{C}$ in a furnace, and immediately stained using the routine Harris hematoxylin-eosin regressive method $\left(\mathrm{HHE}_{2}\right.$; Luna 1968, Howard \& Smith 1983). Digital images were taken with a digital camera mounted on a microscope and transferred to a computer.

\section{Reproductive traits}

Gonad developmental stages (GDS) for each sex were based on the most outstanding histological characteristics specified for the stages used in other holothurians (e.g. Tanaka 1958, Hamel et al. 1993, Herrero-Pérezrul et al. 1999, Hoareau \& Conand 2001, Despalatovi et al. 2004, Shiell \& Uthicke 2006, Toral-Granda \& Martínez 2007, Navarro et al. 2012). The terms used by previous authors and their organization levels include I-resting, II-recovery, IIIgrowth, IV-advanced growth, V-mature stage, VIspent. We used the following 3 criteria to define our GDS: (1) sequence of the biological development process of sexual cells (i.e. gametes) (Menker 1970, Eckelbarger \& Young 1992, Belova \& Viktorovskaya 2007), (2) recruitment of gonadal tubules (Sewell et al. 1997), and (3) mechanisms and functions of the regenerative or resorptive processes of either gonads and/or gonadal-basis after a spawning event (Kille 1936, 1937, Cameron \& Fankboner 1986, CandiaCarnevali et al. 2009).

To quantify reproductive status, 2 indices were calculated for both females and males, as well as for the 2 sexes combined: (1) the traditional gonadosomatic index (GSI, also known as gonad index: GI), which is based on weight relationships: GSI $=[\mathrm{GW} /(\mathrm{TBW}-$ GW)] $\times 100$, and (2) the maturity index (MI) and/or microscopic maturity index (Yoshida 1952, Patent 1969, Sewell 1992, Despalatovi et al. 2004, Meneghetti et al. 2004), which is based on the microscopic GDS: MI $=\sum\left(n_{i} \times s_{i}\right) / N$, where $n_{i}$ is the number of sea cucumbers at each microscopy stage (i.e. GDS), $s_{i}$ is the numerical score attributed to that stage, and $N$ is the total number of sea cucumbers collected monthly. Each MI value indicates its respective gonad developmental stage throughout the collecting period.

Monthly values of fecundity were quantified as the total number of vitellogenic oocytes $\left(F_{\mathrm{vo}}\right)$ per female (actual fecundity), from the mean volume of oocytes and GV in each female. The oocyte volumes (OVs) of at least 100 oocytes sectioned across the nucleus, per female, per month, were calculated assuming a spherical shape $\left[\mathrm{OV}=\left(4 \times \pi \times \mathrm{R}^{3}\right) / 3\right.$ ] and averaged.

Fecundity was estimated as follows:

$$
F_{\mathrm{vo}}=V_{\mathrm{g}} /\left[V_{\mathrm{vo}}+\left(V_{\mathrm{nvo}} \times P\right)\right]
$$

where $V_{\mathrm{g}}=$ volume of the gonad, $V_{\mathrm{vo}}=$ mean volume of a vitellogenic oocyte, $V_{\text {nvo }}=$ mean volume of a nonvitellogenic oocyte, $P=$ ratio between non-vitellogenic and vitellogenic oocytes, i.e. $P=N_{\text {nvo }} / N_{\text {vor }}$ where $N_{\text {nvo }}=$ number of non-vitellogenic oocytes counted on a subsample of 100 oocytes per gonad and $N_{\mathrm{vo}}=$ number of vitellogenic oocytes counted on a subsample of 100 oocytes per gonad (RamírezLlodra 2001, 2002, Ramírez-Llodra et al. 2002).

The diameters of at least 100 oocytes sectioned across the nucleus (i.e. non-vitellogenic 'primary/ secondary' oocytes and vitellogenic oocytes) per female, per month, were measured (Galley et al. 2008) using Feret's diameter measurement (i.e. the longest distance between any 2 points along the selection perimeter; Walton 1948) with the image analysis package ImageJ 1.41. The absolute frequencies of all oocyte diameters were grouped into size ranges each month. The ranges and their amplitude were determined using Sturge's rule (Scherrer 1984).

\section{Statistical analysis}

General data were expressed as mean \pm standard deviation (SD). Sex ratio (male:female) was calculated annually, and deviation from the expected ratio of 1:1 was tested with the chi-square $\left(\chi^{2}\right)$ test. Statistical differences in GSI were tested using 2way ANOVA (sex and month as factors). Differences in fecundity for females were tested using ANOVA. In order to determine the relationship between salinity, temperature, rainfall (pluvial precipitation), and $\mathrm{pH}$ (as independent variables), and the repro- 
ductive cycle of Holothuria fuscocinerea represented by GSI and MI (as dependent variables), we performed a step by step multiple linear regression analysis (forward elimination method). In order to ensure reliability of the results, lack of multicollinearity among independent variables was previously corroborated. Statistical analyses were carried out using STATISTICA ${ }^{\circledR} 6$ (StatSoft) and SigmaStat ${ }^{\circledR} 3.5$ (Systat Software). p $<0.05$ was considered statistically significant.

\section{RESULTS}

\section{Sex ratio}

Holothuria fuscocinerea was confirmed to be a gonochoric species, as not one of the 266 examined individuals was hermaphroditic. They did not show any sexual dimorphism. The annual ratio of males to females did not differ significantly from a 1:1 proportion: $47.76 \%$ of individuals were males, $44.03 \%$ were females $\left(\chi^{2}=14.44, p>0.05\right)$, and the remaining $8.21 \%$ showed gonads in recovery and were 'sexually undifferentiated' (Fig. 1).

\section{Gonad developmental stages}

Based on morphological and histological observations, as well as on the sequence of the developmental process of sexual cells, the GDS for Holothuria fuscocinerea females and males were classified into 4 stages (Figs. $2 \& 3$ ). Gametogenesis (Stage I) corresponds to gonadal tubules with thin walls, characterized by a large production and development of gametogonia (i.e. spermatogonia in males and oogonia in females) which line the gonadal wall. In addition, gametocytes are formed (i.e. spermatocytes and spermatids in males and primary and secondary oocytes in females) which partially fill the lumen of each gonadal tubule. Mature (Stage II) is characterized by a large production of gametes (i.e. spermatozoa in males and vitellogenic oocytes in females) which completely fill each gonadal tubule, the walls of which are still thin. Spawning (Stage III) corresponds to the expulsion of gametes from the gonad, characterized by many empty gaps among the remnant gametes and a thickening of the gonadal wall. Post-spawning (Stage IV) comprises flaccid gonadal tubules with thick walls and an extensive migration of phagocytic hemocytes across remnant gametes in a resorption process.

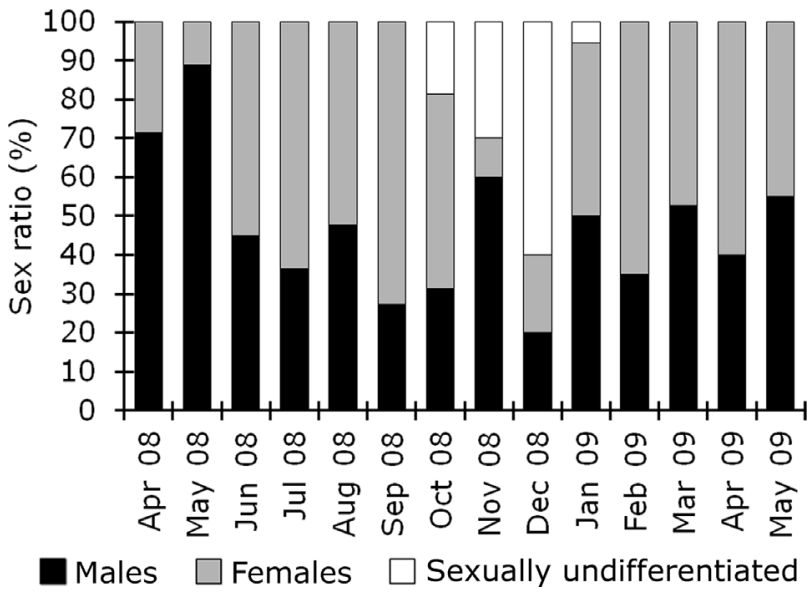

Fig. 1. Holothuria fuscocinerea. Sex ratio from April 2008 to May 2009 at La Entrega Bay, Oaxaca, Mexico

A period of gonadal recovery (classified as Stage $\mathrm{V}$ for both sexes) or a 'sexually undifferentiated' stage was characterized by gonads that macroscopically had a crystalline appearance. Tubules were very short (about $6 \mathrm{~mm}$ in length), and microscopically comprised a large amount of connective tissue that contained germinal cells (called gonadal basis).

\section{Reproductive cycle}

An annual reproductive cycle was observed for Holothuria fuscocinerea. All 4 gonad developmental stages for both sexes showed a pattern of similar frequency between sexes throughout the sampled months; therefore, both sexes were represented together in the reproductive cycle, including the gonad recovery or 'sexually undifferentiated' period (Fig. 4). The gametogenesis stage in both sexes occurred from January to May with high frequencies (above $89 \%$ ) except in April/May (16 to $60 \%$ ). The mature stage in females occurred from April to October 2008 and from February to May 2009 with values oscillating between 11 and $90 \%$, with the highest value in June 2008 (90\%), whereas in males, it occurred from April to July 2008 and from February to May 2009, and frequencies fluctuated between 10 and $56 \%$, with May 2008 being the highest. The spawning stage in females occurred from May to November 2008 with higher frequencies in July $(79 \%)$, August $(75 \%)$, and September $(88 \%)$, whereas in males it was observed from April to October with higher frequencies in June (67\%), July (88\%), and August to September 2008 (100\%). Post-spawning occurred mainly from October to December 2008 for 


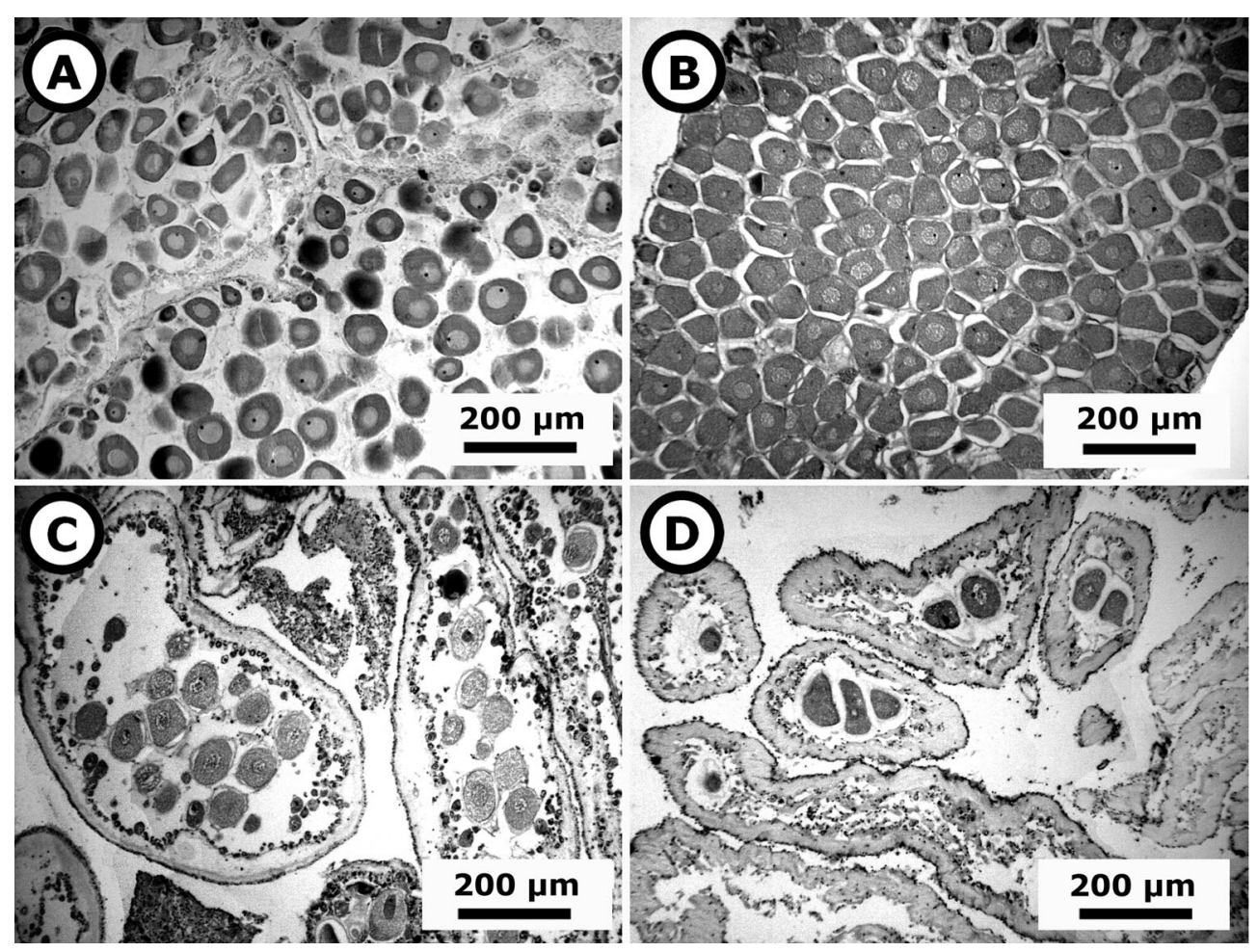

Fig. 2. Holothuria fuscocinerea. Histological sections of the ovaries. (A) Gametogenesis, (B) mature, (C) spawning, (D) postspawning

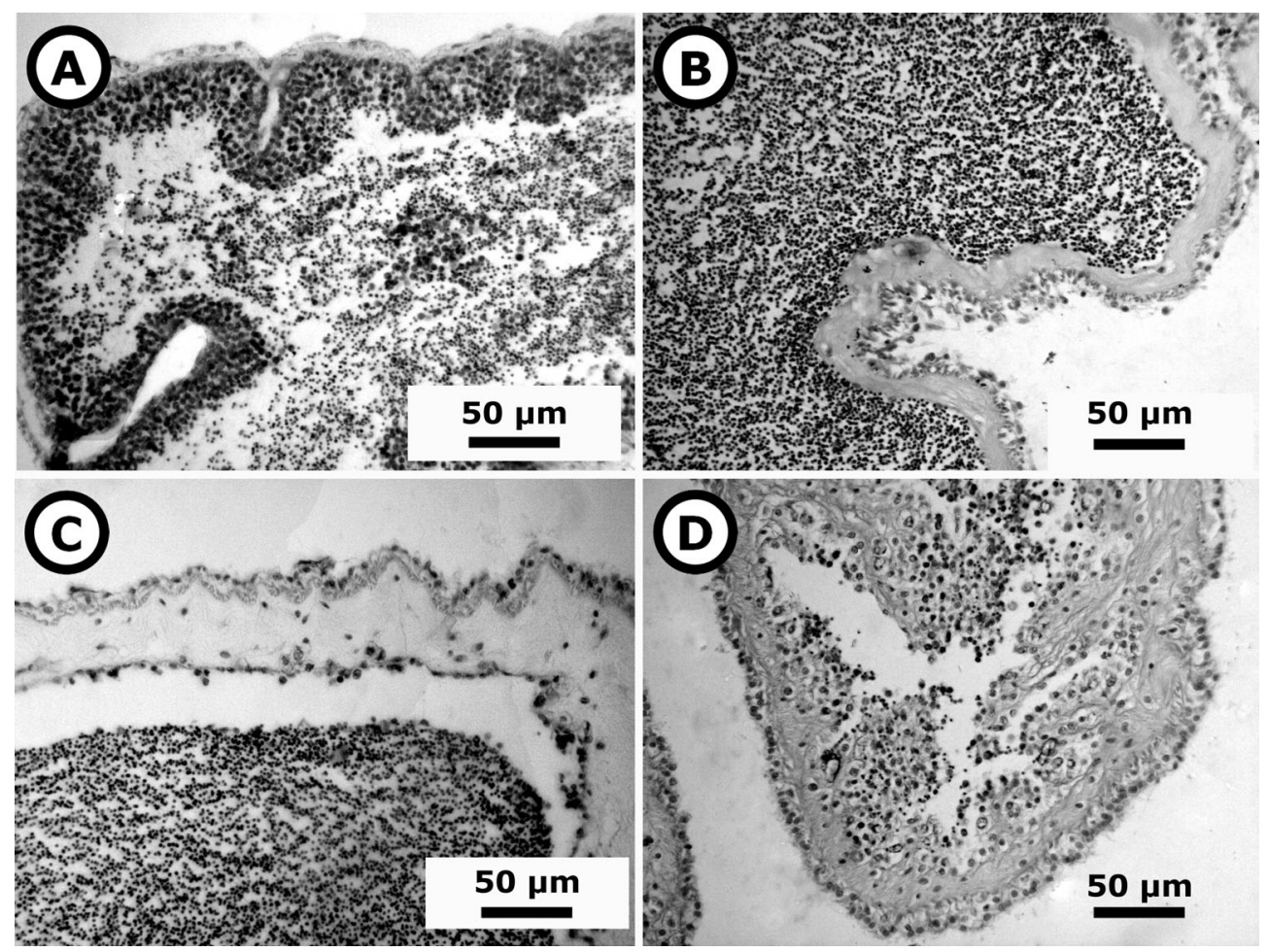

Fig. 3. Holothuria fuscocinerea. Histological sections of the testes. (A) Gametogenesis, (B) mature, (C) spawning, (D) postspawning 


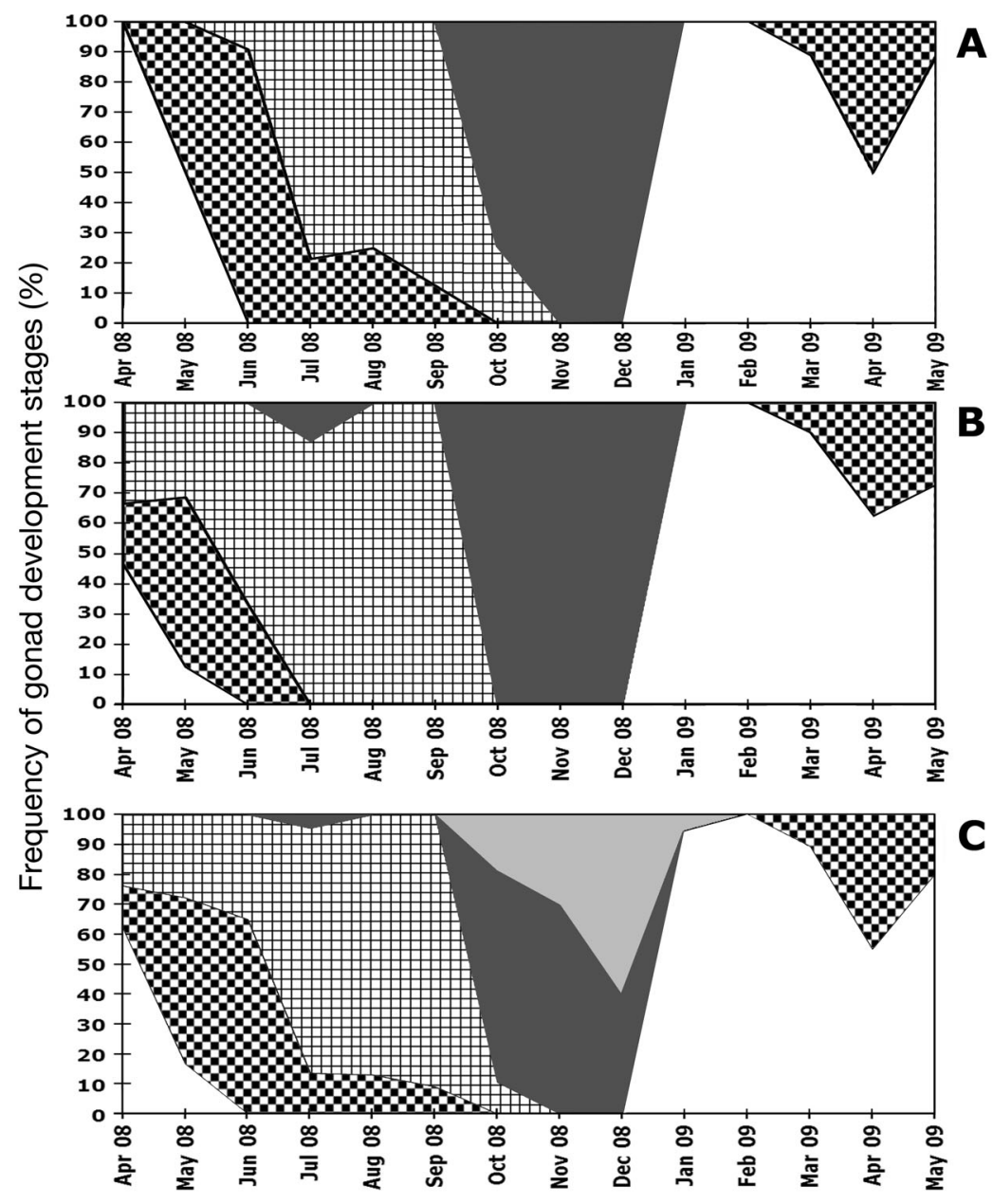

gametogenesis 0 mature

Fig. 4. Holothuria fuscocinerea. Observed reproductive cycle represented as a stacked area derived from the percentage of individuals in each gonad development stage. Studies conducted from April 2008 to May 2009 at La Entrega Bay, Oaxaca, Mexico. (A) Females, (B) males, and (C) combined sexes including the period of gonadal recovery or 'sexually undifferentiated stage' between sexes. Values of GSI in females were higher during May and June 2008. There were also significant differences among months $\left(F_{13,232}=\right.$ 56.340, $\mathrm{p}<0.05)$. The lowest values of the index $(<2)$ occurred from October to February (Fig. 5).

The MI showed gametogenesis (Stage I) and mature (Stage II) from April to June 2008 and from January to May 2009, spawning (Stage III) from July to September 2008, post-spawning (Stage IV) from October to December 2008, and recovery (Stage V) around December 2008 (Fig. 5).

\section{Fecundity}

Actual mean $( \pm \mathrm{SD})$ fecundity of Holothuria fuscocinerea was $2.9 \pm 2.8$ million eggs per female. The maximum fecundity was observed in May 2009 (9.9 million eggs) and the minimum in April 2008 (500000 eggs). In June 2008, a high value of fecundity was observed that decreased in July. Fecundity increased again in August and dropped significantly in September, remaining low until February 2009, when the values started to increase steadily through the next months of sampling. There were significant differences in monthly mean values of fecundity (ANOVA, $F_{(8,74)}=$ 10.95, $\mathrm{p}<0.001)$ both sexes, with the lowest frequency in December $(40 \%)$. Gonadal recovery was observed from September to February 2008, with the highest frequency recorded in December $(60 \%)$ and the lowest in January (6\%) (Fig. 4).

\section{Gonadosomatic and maturity indices}

The GSI showed the same pattern of fluctuation between sexes but was slightly more pronounced in females than in males. Males showed GSI values between 0.57 and 11.11, and females showed values between 0.56 and 20.51. The statistical analyses showed significant differences $\left(F_{1,232}=33.857, \mathrm{p}<0.05\right)$

\section{Diameter and distribution of oocytes}

The mean diameter $( \pm \mathrm{SD})$ of all oocytes $(\mathrm{n}=10642$, non-vitellogenic 'primary/secondary' oocytes and vitellogenic oocytes) was $117.70 \pm 53.27 \mu \mathrm{m}$, with the highest diameters $(306-308 \mu \mathrm{m})$ recorded during July and August 2008, and the lowest diameters $(<40 \mu \mathrm{m})$ from November 2008 to May 2009. Mean diameter $( \pm \mathrm{SD})$ of non-vitellogenic oocytes (i.e. primary/secondary) was $61.46 \pm 9.83 \mu \mathrm{m}$, whereas vitellogenic oocytes (i.e. mature) had an average diameter of $121.49 \pm 31.37 \mu \mathrm{m}$. The highest frequencies of the non-vitellogenic oocytes $(<80 \mu \mathrm{m})$ occurred during November (55\%) and December (49\%) 2008, as well as in April (35\%) and May (46\%) 2008 and in 


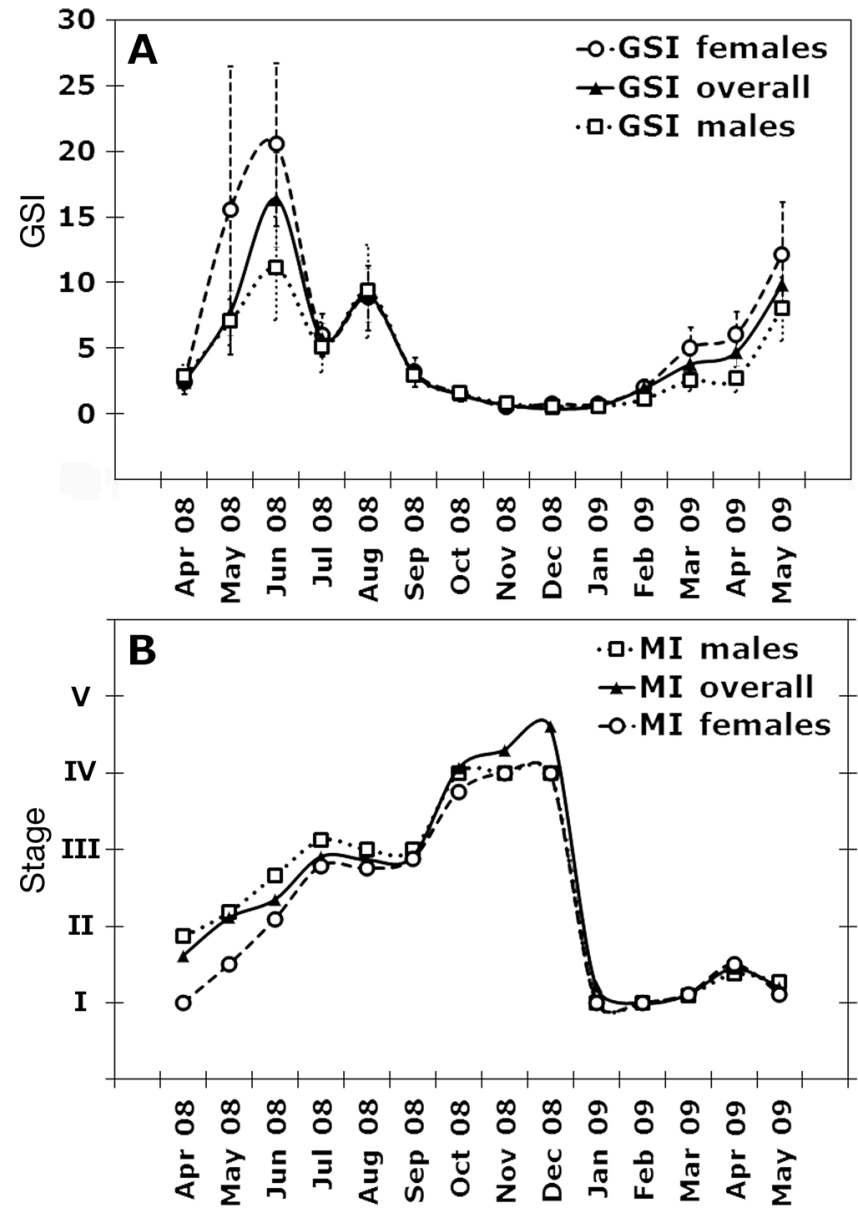

Fig. 5. Holothuria fuscocinerea. Reproductive indices at La Entrega Bay, Oaxaca, Mexico. (A) Monthly means ( \pm SD) of the gonadosomatic index (GSI). (B) Maturity index and/or microscopic maturity index (MI)

February (38\%) 2009. From June (27\%) until September $(64 \%) 2008$, the ovaries almost exclusively comprised vitellogenic oocytes $(>140 \mu \mathrm{m})$ with a tendency for these to increase in frequency, the highest frequencies occurring during August (41\%) and September (64\%) 2008. Subsequently, the frequency of vitellogenic oocytes tended to decrease (October 2008, $53 \%$ ) as that of non-vitellogenic oocytes increased (November 2008, $55 \%$ ) (Fig. 6).

\section{Spawning (reproductive season) versus environmental factors}

During the spawning period (July to October), the temperature $(\mathrm{T})$ was higher than $29^{\circ} \mathrm{C}$, and the rainfall values (pluvial precipitation, PP) were larger than $245 \mathrm{~mm}$. Salinity (S) increased from 30.6 to 31.7, and pH decreased from 9.0 to 8.4 (Fig. 7).
A step by step multiple regression analysis of GSI pooled for both sexes of Holothuria fuscocinerea with respect to the environmental factors was performed, resulting in the following model:

GSI $=-28.296+0.00672 \times \mathrm{PP}\left(\mathrm{R}^{2}=0.29, \mathrm{p}<0.05\right)(2)$

The model showed that PP explained $29 \%$ of the total variance of GSI.

No variable was selected in the analysis to predict MI pooled for both sexes of Holothuria fuscocinerea.

\section{DISCUSSION}

The gonad developmental cycle described for Holothuria fuscocinerea is similar to that registered for other holothurian species with synchronic seasonal reproduction (Fajardo-León et al. 1995, TapiaVázquez et al. 1996, Rasolofonirina et al. 2005, Tehranifard et al. 2006, Asha \& Muthiah 2008). Our results (reproductive cycle, reproductive indices, fecundity, and oocyte diameter distribution) showed convergence with the gonad developmental stages, providing strong evidence to indicate that $H$. fuscocinerea exhibits an annual reproductive season (spawning) in Oaxaca $\left(\sim 15^{\circ} \mathrm{N}, 96^{\circ} \mathrm{W}\right)$, which occurs from June through September (summer). Similarly, other sea cucumbers such as Parastichopus parvimensis (Tapia-Vázquez et al. 1996) and Isostichopus fuscus (Fajardo-León et al. 1995, Herrero-Pérezrul et al. 1999), both from Baja California $\left(\sim 27^{\circ} \mathrm{N}, 112^{\circ} \mathrm{W}\right)$, spawn during the same period.

Pearse (1968) and Giese \& Pearse (1974) established that seasonality in reproductive cycles of marine invertebrates tends to be stronger as the latitude increases. Cameron \& Fankboner (1986) and Conand (1993) mentioned that seasonal reproductive cycles in holothurians are characteristic of most temperate species, whose spawning season occurs as a consequence of increasing temperature, as well as of the extent and intensity of daylight, implying an increase in phytoplankton biomass and, in turn, a larger supply of food for sea cucumbers.

In this study Holothuria fuscocinerea did not exhibit the characteristic patterns of a continuous reproductive cycle which might be expected considering that it is a tropical species and taking into account that most cycles are timed so that the production of larvae or juveniles are synchronized with periods favorable for feeding or survival (Giese \& Pearse 1974). In contrast, our results showed a synchrony between sexes for spawning, suggesting a close relationship with the local oceanic dynamics. 

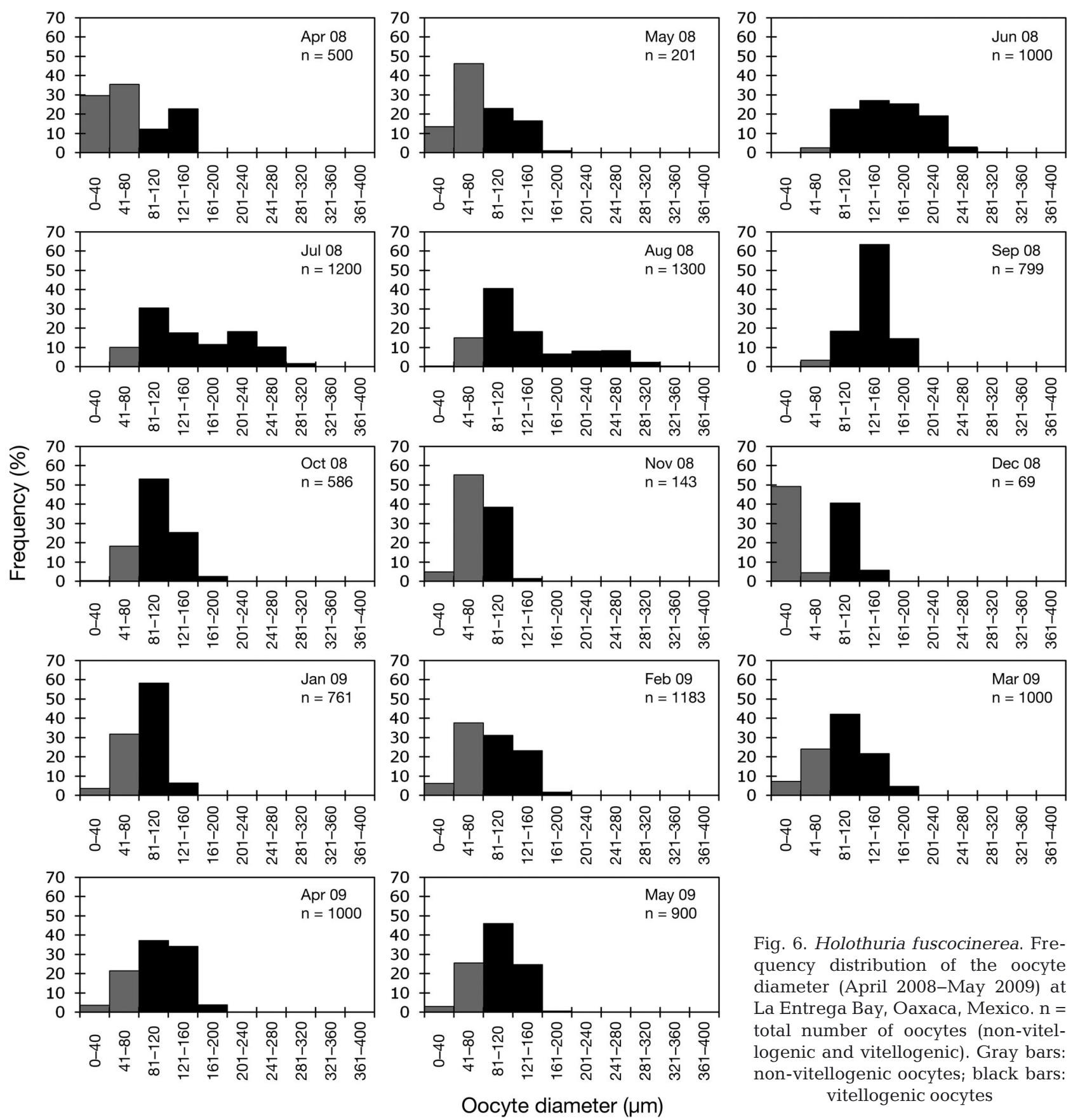

Fig. 6. Holothuria fuscocinerea. Frequency distribution of the oocyte diameter (April 2008-May 2009) at La Entrega Bay, Oaxaca, Mexico. $\mathrm{n}=$ total number of oocytes (non-vitellogenic and vitellogenic). Gray bars: non-vitellogenic oocytes; black bars: vitellogenic oocytes

Similarly, other echinoderm species in the area, such as the brittle stars Ophiocoma aethiops and $O$. alexandri (Benítez-Villalobos et al. 2012) and the starfish Pharia pyramidatus (Benítez-Villalobos \& Martínez-García 2012) as well as other invertebrates such as the mollusk Chiton articulatus (Avila-Poveda 2013), have shown an annual reproductive season (spawning) around summer (June to September).

Although the study site of Holothuria fuscocinerea corresponds to a tropical locality and fluctuations of oceanographic variables are apparently minimal and the availability of food is theoretically constant, there are local oceanic processes, such as upwelling in the Gulf of Tehuantepec between November and May, that are strongly influenced by the action of important winds known locally as Nortes (Trasviña \& Barton 1997, Tapia-García et al. 2007). Furthermore, there is a remarkable difference between the rainy (May to October) and dry seasons (November to April) which determines well-defined seasonal ocean- 

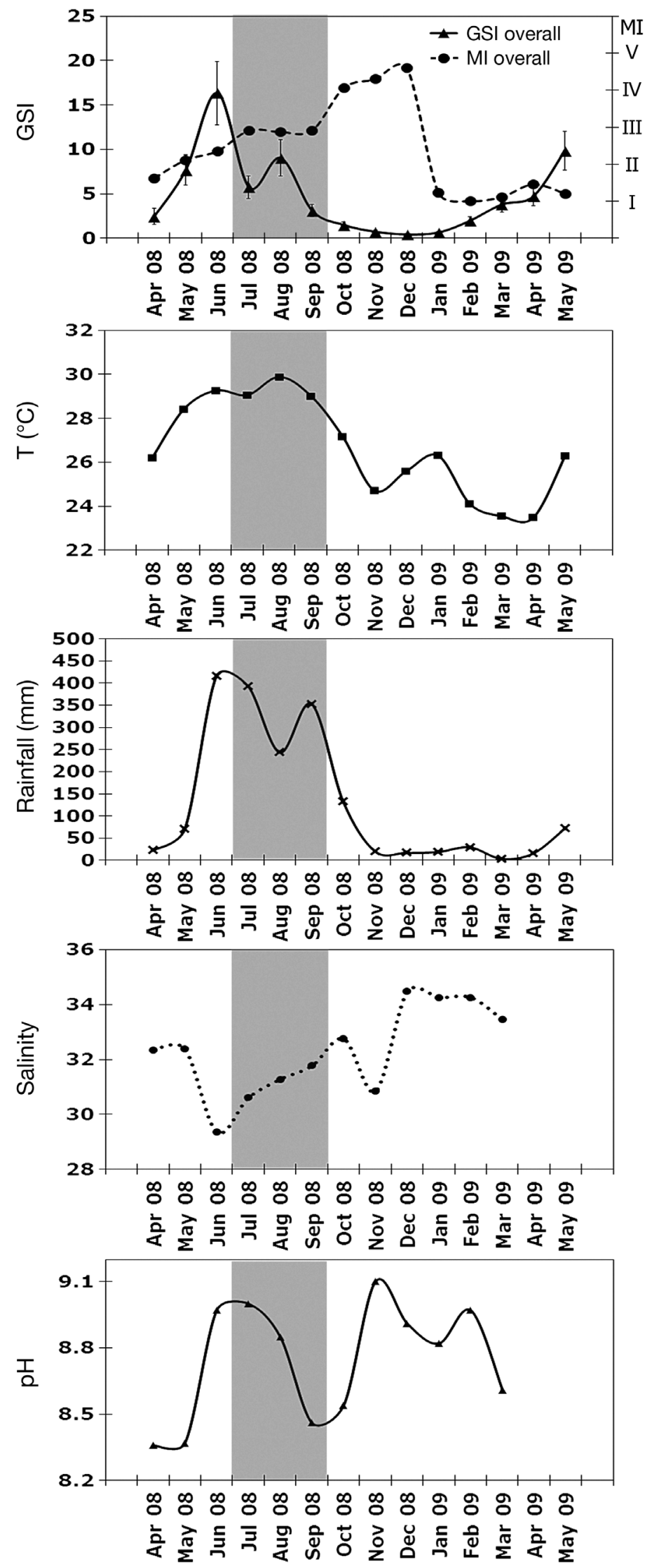

ographic regimes. An increase in seawater temperature produces the rainfall season, and during this season, seawater salinity decreases. On the other hand, the absence of rainfall and high evaporation generates an increase in salinity, and the action of the Nortes produces a decline in temperature between November and May due to upwelling (Trasviña \& Barton 1997, Tapia-García et al. 2007).

Our statistical analyses show that temporal variations in rainfall were significantly related to the GSI and had important effects on the reproductive cycle of Holothuria fuscocinerea. Spawning was evidently influenced by a high primary production associated with the extensive runoff produced by pluvial precipitation, which increases the nutrient supply to the ocean (Birkeland 1982). This in turn, increases the phytoplankton production in the water column that provides an important source of food for planktonic larvae (Strathmann et al. 1992). Additionally, during this spawning period the adult organisms also benefit from this organic abundance, as the detritus that is used as food is also enriched by the deposition of plankton products and organic matter that reaches the sea bottom a short period after the surface layer stabilizes (Hamel et al. 1993, Asha \& Muthiah 2008). This fact has been documented for other holothurian species such as $H$. leucospilota (Jayasree \& Bhavanarayana 1994), H. scabra (Rasolofonirina et al. 2005) and $H$. spinifera (Asha \& Muthiah 2008).

The marked differences between dry and rainfall seasons and strong upwelling influence the biological processes of the communities at an evolutionary level, determining the seasonal reproductive patterns observed in Holothuria fuscocinerea and other echinoderm species in the area, such as the starfish Pharia pyramidatus (Benítez-Villalobos \& MartínezGarcía 2012) and the brittle stars Ophiocoma aethiops and O. alexandri (Benítez-Villalobos et al. 2012).

In marine invertebrates, there is a trade-off between fecundity and the amount of energy that can be invested in each egg. Thus, as a rule, a species produces either many small eggs with planktotrophic

Fig. 7. Holothuria fuscocinerea. Reproductive season (spawning) shown by reproductive indices (GSI: gonadosomatic index and MI: microscopic maturity index), and monthly means of temperature, pluvial precipitation (rainfall), salinity and pH, from April 2008 to May 2009, at La Entrega Bay, Oaxaca, Mexico. Gray area indicates spawning period. Levels of MI are: Stage I, gametogenesis; Stage II, mature; Stage III, spawning; Stage IV, post-spawning; Stage V, recovery 
development or fewer, large eggs with lecithotrophic development (Thorson 1950). Sewell \& Young (1997) proposed that holothuroids with eggs from 50 to about $300 \mu \mathrm{m}$ show planktotrophic development. Therefore, considering the high average fecundity and relatively small mean egg size estimated for Holothuria fuscocinerea in this work, we propose that this species shows a reproductive strategy that includes a planktotrophic larva (Strathmann et al. 1992, Ramírez-Llodra 2002). Planktotrophic larvae depend principally on food availability in the water column because their eggs are provisioned with insufficient energy reserves. Consequently, species that have this kind of larvae generally couple their spawning season with rainfall periods because there is an increase in primary production at that time. This ensures that the larvae are able to feed and survive (McEdward \& Miner 2003, Reitzel et al. 2004), as apparently occurs with the reproductive cycle of $H$. fuscocinerea off the coast of Oaxaca.

Furthermore, during the post-spawning season of Holothuria fuscocinerea (October to January) when the lowest values of GSI $(<2)$ were recorded, the presence of 'sexually undifferentiated' individuals was noted; this appeared to be the result of a gonad resorption process, and these individuals were classified as being in the recovery stage (Stage V), with the highest values during November and December. This process of resorption and disappearance of gonads has been reported for a number of species of holothurians at different latitudes (Tyler et al. 1985, Fajardo-León et al. 1995, Tapia-Vázquez et al. 1996, Herrero-Pérezrul et al. 1999, Hoareau \& Conand 2001, Rasolofonirina et al. 2005), and it is considered a common phenomenon in species of the order Aspidochirotida (Kille 1936, 1937) around post-spawning (Cameron \& Fankboner 1986). Apparently, this reproductive strategy that cleans the gonad for the next reproductive cycle involves an energy cost that is reflected in a prolonged gametogenesis stage lasting about 6 mo in Holothuria fuscocinerea, as shown by the MI and the reproductive cycle.

Acknowledgements. This work is part of the BSc thesis of I.S.G.-M. at the Universidad del Mar 'UMAR'. The present study was financed by the Project 'Patrones reproductivos de tres especies de equinodermos asociados a arrecife en la costa de Oaxaca' supported by PROMEP (2IR0707) to F.B.-V. The specific research permit (No. DGOPA.02934.250308. 0646) for the collection of the specimens throughout the sampling period was acquired with the project. The histological procedure and analyses were carried out at the histology laboratory of the UMAR. This manuscript was improved considerably by comments from 3 anonymous referees.

\section{LITERATURE CITED}

Abdel-Razek FA, Abdel-Rahman SH, El-Shimy NA, Omar HA (2005) Reproductive biology of the tropical sea cucumber Holothuria atra (Echinodermata: Holothuroidea) in the Red Sea coast of Egypt. Egypt J Aquat Res 31: 383-402

Aguilar-Ibarra A, Ramírez-Soberón G (2002) Economic reasons, ecological actions and social consequences in the Mexican sea cucumber fishery. SPC Beche-de-Mer Inf Bull 17:33-36

Anderson SC, Flemming JM, Watson R, Lotze HK (2011) Serial exploitation of global sea cucumber fisheries. Fish Fish 12:317-339

> Andrew NL, Béné C, Hall SJ, Allison EH, Heck S, Ratner BD (2007) Diagnosis and management of small-scale fisheries in developing countries. Fish Fish 8:227-240

- Asha PS, Muthiah P (2008) Reproductive biology of the commercial sea cucumber Holothuria spinifera (Echinodermata: Holothuroidea) from Tuticorin, Tamil Nadu, India. Aquacult Int 16:231-242

Avila-Poveda OH (2013) Annual change in morphometry and in somatic and reproductive indices of Chiton articulatus adults (Polyplacophora: Chitonidae) from Oaxaca, Mexican Pacific. Am Malacol Bull 31:65-74

Baillon S, Hamel JF, Mercier A (2011) Comparative study of reproductive synchrony at various scales in deep-sea echinoderms. Deep-Sea Res I 58:260-272

Belova GV, Viktorovskaya GI (2007) Morphometric characteristic of sex cells and seasonal changes of female gonads of Cucumaria japonica (Semper, 1868) (Echinodermata: Holothuroidea) from Peter the Great Bay, Sea of Japan. Russ J Mar Biol 33:173-180

Benítez-Villalobos F, Martínez-García M (2012) Reproductive biology of the starfish Pharia pyramidatus (Echinodermata: Asteroidea) from the Mexican tropical Pacific. J Mar Biol Assoc UK 92:1409-1418

> Benítez-Villalobos F, Aguilar-Duarte C, Avila-Poveda $\mathrm{OH}$ (2012) Reproductive biology of Ophiocoma aethiops and O. alexandri (Echinodermata: Ophiuroidea) from Estacahuite Bay, Oaxaca, Mexico. Aquat Biol 17:119-128

Birkeland C (1982) Terrestrial runoff as a cause of outbreaks of Acanthaster planci (Echinodermata: Asteroidea). Mar Biol 69:175-185

Byrne M, Morrice MG, Wolf B (1997) Introduction of the northern Pacific asteroid Asterias amurensis to Tasmania: reproduction and current distribution. Mar Biol 127: 673-685

Cameron JL, Fankboner PV (1986) Reproductive biology of the commercial sea cucumber Parastichopus californicus (Stimpson) (Echinodermata: Holothuroidea). I. Reproductive periodicity and spawning behavior. Can J Zool 64:168-175

Candia-Carnevali MD, Thorndyke MC, Matranga V (2009) Regenerating echinoderms: a promise to understand stem cells potential, Chap 7. In: Rinkevich B, Matranga V (eds) Stem cells in marine organisms. Springer, New York, NY, p 165-186

Carvalho ALPS, Ventura CRR (2002) The reproductive cycle of Asterina stellifera (Möbius) (Echinodermata: Asteroidea) in the Cabo Frio region, southeastern Brazil. Mar Biol 141:947-954

Castro LRS (1995) Management options of the commercial dive fisheries for sea cucumbers in Baja California, Mexico. SPC Beche-de-Mer Inf Bull 7:20 
Conand C (1993) Reproductive biology of the holothurians from the major communities of the New Caledonian Lagoon. Mar Biol 116:439-450

Conand C (2001) Overview of sea cucumbers fisheries over the last decade - what possibilities for a durable management? In: Barker M (ed) Echinoderms 2000. Swets \& Zeitlinger, Lisse, p 339-344

Conand C (2004) Present status of world sea cucumber resources and utilisation: an international overview. In: Lovatelli A, Conand C, Purcell S, Uthicke S, Hamel JF, Mercier A (eds) Advances in sea cucumber aquaculture and management. FAO Fish Tech Paper No. 463. FAO, Rome, p 13-23

Conand C, Byrne M (1993) A review of recent developments in the world sea cucumber fisheries. Mar Fish Rev 55: $1-13$

Conand C, Sloan NA (1989) World fisheries for echinoderms. In: Caddy JF (ed) Marine invertebrate fisheries: their assessment and management. Wiley, New York, NY, p 647-663

Despalatovi M, Grubeli I, Šimunovi A, Antoli B, Ante Žuljevi (2004) Reproductive biology of the holothurian Holothuria tubulosa (Echinodermata) in the Adriatic Sea. J Mar Biol Assoc UK 84:409-414

> Eckelbarger KJ, Young CM (1992) Ovarian ultrastructure and vitellogenesis in ten species of shallow-water and bathyal sea cucumbers (Echinodermata: Holothuroidea). J Mar Biol Assoc UK 72:759-781

Fajardo-León MC, Michel-Guerrero E, Singh-Cabanillas J, Vélez-Barajas JA, Massó-Rojas A (1995) Estructura poblacional y ciclo reproductor del pepino de mar Isostichopus fuscus en Santa Rosalía, B.C.S., México. Cienc Pesq 11:45-53 (in Spanish with English abstract)

Galley EA, Tyler PA, Smith CR, Clarke A (2008) Reproductive biology of two species of holothurians from the deepsea order Elasipoda, on the Antarctic continental shelf. Deep-Sea Res II 55:2515-2526

Gaudron SM, Kohler SA, Conand C (2008) Reproduction of the sea cucumber Holothuria leucospilota in the western Indian Ocean: biological and ecological aspects. Invertebr Reprod Dev 51:19-31

Giese AC, Pearse JS (1974) Reproduction: general principles. In: Giese AC, Pearse JS (eds) Reproduction of marine invertebrates, Vol 1. Academic Press, New York, NY, p 1-49

> Gutt J, Gerdes D, Klages M (1992) Seasonality and spatial variability in the reproduction of two Antarctic holothurians (Echinodermata). Polar Biol 11:533-544

Guzmán HM, Guevera CA (2002) Annual reproductive cycle, spatial distribution, abundance, and size structure of Oreaster reticulatus (Echinodermata: Asteroidea) in Bocas del Toro, Panama. Mar Biol 141:1077-1084

> Hamel JF, Himmelman JH, Dufresne L (1993) Gametogenesis and spawning of the sea cucumber Psolus fabricii (Duben and Koren). Biol Bull 184:125-143

> Herrero-Pérezrul MD, Reyes-Bonilla H, García-Domínguez F, Cintra-Buenrostro CE (1999) Reproduction and growth of Isostichopus fuscus (Echinodermata: Holothuroidea) in the southern Gulf of California, México. Mar Biol 135: 521-532

Hickman CP (1998) A field guide to sea stars and other echinoderms of Galápagos. Sugar Spring Press, Lexington, VA

Hoareau T, Conand C (2001) Sexual reproduction of Stichopus chloronotus, a fissiparous sea cucumber, on Reunion
Island, Indian Ocean. SPC Beche-de-Mer Inf Bull 15: $4-12$

Howard DW, Smith CS (1983) Histological techniques for marine bivalve mollusks. NOAA Tech Memo NMFSF/ NEC-25. NOAA, Woods Hole, MA

Hudson IR, Wigham BD, Billett DSM, Tyler PA (2003) Seasonality and selectivity in the feeding ecology and reproductive biology of deep-sea bathyal holothurians. Prog Oceanogr 59:381-407

Humason GL (1962) Animal tissue techniques. WH Freeman \& Co, San Francisco, CA

Jayasree V, Bhavanarayana PV (1994) Reproduction in Holothuria (Mertensiothuria) leucospilota (Brandt) from Anjuna, Goa. Bull Cent Mar Fish Res Inst 46:57-62

Kille FR (1936) Regeneration in holothurians. Annu Rep Tortugas Lab, Carnegie Inst Washington, Year Book 35: 85-86

Kille FR (1937) Regeneration in the genus Holothuria. Annu Rep Tortugas Lab, Carnegie Inst Washington, Year Book 36:93-94

Lessios HA (1981) Reproductive periodicity of the echinoids Diadema and Echinometra on the two coasts of Panama. J Exp Mar Biol Ecol 50:47-61

Lovatelli A, Conand C, Purcell S, Uthicke S, Hamel JF, Mercier A (2004) Advances in sea cucumber aquaculture and management. FAO Fish Tech Paper No. 463. FAO, Rome

Luna LG (1968) Manual of histologic staining methods of the Armed Forces Institute of Pathology. McGraw-Hill Book Company, New York, NY

Martinez MI, Giménez J, Penchaszadeh PE (2011) Reproductive cycle of the sea cucumber Psolus patagonicus Ekman 1925, off Mar del Plata, Buenos Aires, Argentina. Invertebr Reprod Dev 55:124-130

McEdward LR, Miner BG (2003) Fecundity-time models of reproductive strategies in marine benthic invertebrates: fitness differences under fluctuating model environmental conditions. Mar Ecol Prog Ser 256:111-121

Meneghetti F, Moschino V, Da Ros L (2004) Gametogenic cycle and variations in oocyte size of Tapes philippinarum from the Lagoon of Venice. Aquaculture 240:473-488

Menker D (1970) Lebenszyklus, Jugendentwicklung und Geschlechtsorgane von Rhabdomolgus ruber (Holothuroidea: Apoda). Mar Biol 6:167-186 (in German)

Muñeton-Gómez MS, Villalejo-Fuerte M, García-Melgar G (2000) Manual de técnicas histológicas aplicadas a organismos marinos. UABCS, La Paz (in Spanish)

> Muthiga NA (2006) The reproductive biology of a new species of sea cucumber, Holothuria (Mertensiothuria) arenacava in a Kenyan marine protected area: the possible role of light and temperature on gametogenesis and spawning. Mar Biol 149:585-593

> Muthiga NA, Kawaka JA (2009) The breeding pattern and variations in timing and reproductive output of the commercial sea cucumber Holothuria fuscogilva in Kenya. West Indian Ocean J Mar Sci 8:183-192

Nagy IZ, Pieri C (1975) A new method for very precise volumetry of organs of irregular shape. Mikroskopie 31: 70-72

Navarro PG, García-Sanz S, Tuya F (2012) Reproductive biology of the sea cucumber Holothuria sanctori (Echinodermata: Holothuroidea). Sci Mar 76:741-752

$>$ Patent DH (1969) The reproductive cycle of Gorgonocephalus caryi (Echinodermata: ophiuroidea). Biol Bull 136:241-252 
Pearse JS (1968) Patterns of reproductive periodicities in four species of Indo-Pacific echinoderms. Proc Indiana Acad Sci 67B:247-279

Priddle J, Hawes I, Ellis-Evans JC, Smith TJ (1986) Antarctic aquatic ecosystems as habitats for phytoplankton. Biol Rev Camb Philos Soc 61:199-238

Purcell SW, Lovatelli A, Vasconcelos M, Ye Y (2010) Managing sea cucumber fisheries with an ecosystem approach. FAO Fish Aquacult Tech Paper No. 520. FAO, Rome

Purcell SW, Mercier A, Conand C, Hamel JF, Toral-Granda MV, Lovatelli A, Uthicke S (2013) Sea cucumber fisheries: global analysis of stocks, management measures and drivers of overfishing. Fish Fish 14:34-59

Ramírez-Llodra E (2001) Reproductive patterns of deep-sea invertebrates related to energy availability. $\mathrm{PhD}$ dissertation, University of Southampton, Southampton

Ramírez-Llodra E (2002) Fecundity and life-history strategies in marine invertebrates. Adv Mar Biol 43:87-170

Ramírez-Llodra E, Tyler PA, Billett DSM (2002) Reproductive biology of porcellanasterid asteroids from three abyssal sites in the northeast Atlantic with contrasting food input. Mar Biol 140:773-788

Ramofafia C, Byrne M, Battaglene S (2001) Reproductive biology of the intertidal sea cucumber Actinopyga mauritiana in the Solomon islands. J Mar Biol Assoc UK 81: 523-531

Rasolofonirina R, Vaïtilingon D, Eeckhaut I, Jangoux M (2005) Reproductive cycle of edible echinoderms from the southwestern Indian Ocean. II. The sandfish Holothuria scabra (Jaëger, 1833). West Indian Ocean J Mar Sci 4:61-75

Reichenbach N (1999) Ecology and fishery biology of Holothuria fuscogilva (Echinodermata: Holothuroidea) in the Maldives, Indian Ocean. Bull Mar Sci 64:103-113

Reitzel AM, Miner BG, McEdward LR (2004) Relationships between spawning date and larval development time for benthic marine invertebrates: a modeling approach. Mar Ecol Prog Ser 280:13-23

Rubilar T, Pastor de Ward CT, Díaz de Vivar ME (2005) Sexual and asexual reproduction of Allostichaster capensis (Echinodermata: Asteroidea) in Golfo Nuevo. Mar Biol 146:1083-1090

SAGARPA (Secretaria de Agricultura, Ganadería, Desarrollo Rural, Pesca y Alimentación) (2012) DOF-24-AUG2012: ACUERDO por el que se da a conocer la Actualización de la Carta Nacional Pesquera. www.inapesca. gob.mx/portal/publicaciones/carta-nacional-pesquera (accessed 2 November 2012) (in Spanish)

Scherle W (1970) A simple method for volumetry of organs in quantitative stereology. Mikroskopie 26:57-60

Scherrer B (1984) Biostatistique. Gaëtan Morris éditeur, Québec (in French)

Sewell MA (1992) Reproduction of the temperate Aspidochirote Stichopus mollis (Echinodermata: Holothuroidea) in New Zealand. Ophelia 35:103-121

- Sewell MA, Young CM (1997) Are echinoderm egg size distributions bimodal? Biol Bull 193:297-305

Sewell MA, Tyler PA, Young CM, Conand C (1997) Ovarian development in the class Holothuroidea: a reassessment of the 'tubule recruitment model'. Biol Bull 192:17-26

Shiell GL, Uthicke S (2006) Reproduction of the commercial sea cucumber Holothuria whitmaei [Holothuroidea: Aspidochirotida] in the Indian and Pacific Ocean regions

Editorial responsibility: Yoichi Yusa,

Nara, Japan of Australia. Mar Biol 148:973-986

SMN-CNA (Servicio Meteorológico Nacional, Comisión Nacional del Agua) (2009) Climatología: temperatura y precipitación. http://smn.cna.gob.mx/ (accessed 2 June 2009) (in Spanish with English abstract)

Solís-Marín FA, Reyes-Bonilla H, Herrero-Pérezrul MD, Arizpe-Covarrubias O, Laguarda-Figueras A (1997) Sistemática y distribución de los equinodermos de la Bahía de La Paz. Cienc Mar 23:249-263) (in Spanish with English abstract)

Stanwell-Smith D, Clarke A (1998) Seasonality of reproduction in the cushion star Odontaster validus at Signy Island, Antarctica. Mar Biol 131:479-487

Strathmann RR, Fenaux L, Strathmann MF (1992) Heterochronic developmental plasticity in larval sea urchins and its implications for evolution of nonfeeding larvae. Evolution 46:972-986

Tanaka Y (1958) Seasonal changes occurring in the gonad of Stichopus japonicus. Bull Fac Fish Hokkaido Univ 9: 29-37

Tapia-García M, García-Abad MC, Carranza-Edwards A, Vázquez-Gutiérrez F (2007) Environmental characterization of the continental shelf of the Gulf of Tehuantepec, Mexico. Geofis Int 46:249-260

Tapia-Vázquez OM, Castro-González JJ, Valles-Ríos H (1996) Madurez gonádica del pepino de mar Parastichopus parvimensis en la costa occidental de Baja California, México, en 1994. Cienc Pesq 12:5-12 (in Spanish with English abstract)

Tehranifard A, Uryan S, Vosoghi G, Fatemy SM, Nikoyan A (2006) Reproductive cycle of Stichopus herrmanni from Kish Island, Iran. SPC Beche-de-Mer Inf Bull 24:22-27

Teo S, Ng CSL, Loh KS (2010) New record of a sea cucumber, Holothuria (Stauropora) fuscocinerea Jaeger, 1833 (Holothuroidea: Aspidochirotida: Holothuriidae) in Singapore. Nat Singapore 3:133-137

Thorson G (1950) Reproductive and larval ecology of marine bottom invertebrates. Biol Rev Camb Philos Soc 25:1-45

Tiensongrusmee B, Pontjoprawiro S (1988) Sea cucumber culture: potential and prospects. FAO project report No. 14, AC869/E. FAO, Rome

> Toral-Granda MV, Martínez PC (2007) Reproductive biology and population structure of the sea cucumber Isostichopus fuscus (Ludwig, 1875) (Holothuroidea) in Caamaño, Galápagos Islands, Ecuador. Mar Biol 151: 2091-2098

Toral-Granda V, Lovatelli A, Vasconcellos M (2008) Sea cucumbers: a global review of fisheries and trade. FAO Fish Aquacult Tech Paper No. 516. FAO, Rome

Trasviña A, Barton ED (1997) Los 'Nortes' del Golfo de Tehuantepec: la circulación costera inducida por el viento, Chap 2. In: Lavín MF (ed) Contribuciones a la oceanografía física en México, Monografía No. 3. Unión Geofísica Mexicana, Ensenada, p 25-46 (in Spanish)

> Tyler PA, Gage JD, Billett DSM (1985) Life-history biology of Peniagone azorica and $P$. diaphana (Echinodermata: Holothurioidea) from the north-east Atlantic Ocean. Mar Biol 89:71-81

Walton WH (1948) Feret's statistical diameter as a measure of particle size. Nature 162:329-330

Yoshida M (1952) Some observations on the maturation of the sea urchin, Diadema setosum. Annot Zool Jpn 25: 265-271

Submitted: December 18, 2012; Accepted: May 29, 2013

Proofs received from author(s): June 22, 2013 